\title{
Genetic Analysis and Molecular Mapping of Quantitative Trait Loci in Common Bean Against Pythium ultimum
}

\author{
Ana Campa, Elena Pérez-Vega, Aida Pascual, and Juan José Ferreira
}

Área de Cultivos Hortofrutícolas y Forestales, Servicio Regional de Investigación y Desarrollo Agroalimentario (SERIDA), 33300,

Villaviciosa, Asturias, Spain.

Accepted for publication 31 July 2010.

\section{ABSTRACT}

Campa, A., Pérez-Vega, E., Pascual, A., and Ferreira, J. J. 2010. Genetic analysis and molecular mapping of quantitative trait loci in common bean against Pythium ultimum. Phytopathology 100:1315-1320.

Pythium ultimum is a soil pathogen that can cause seed decay and damage to roots in common bean. In this study, the response of a set of 40 common bean genotypes to $P$. ultimum and inheritance of the resistance in the $92 \mathrm{~F}_{7}$ recombinant inbred lines (RIL) developed from a cross between Xana and Cornell 49242 was investigated by using emergence rate and seedling vigor. Emergence of the 40 genotypes showed a significant association between white seed coat and response to this pathogen. Among these, 11 common bean genotypes, all with colored seeds, exhibited a high percentage of emergence and seedling vigor not significantly different $(P>0.05)$ to noninoculated plants. Response of the RIL population revealed both qualitative and quantitative modes of inheri- tance. A major gene $(P y-1)$ controlling the emergence rate was mapped in the region of the gene $P$, a basic color gene involved in control of seed coat color, located on LG 7. Using the RIL subpopulation with colored seeds, a significant quantitative trait loci (QTL) associated with the emergence rate $\left(\mathrm{ER} 3^{\mathrm{XC}}\right)$ and another with seedling vigor $\left(\mathrm{SV} 6^{\mathrm{XC}}\right)$ were identified on the LG 3 and 6, respectively. QTL SV6 ${ }^{\mathrm{XC}}$ was mapped in the region of the gene $V$, another gene involved the genetic control of color. QTLs associated with seed traits were mapped in the same relative position as regions involved in responses to $P$. ultimum suggesting the possible implication of avoidance mechanisms in the response to this pathogen.

Additional keywords: breeding program, genetic map, physiological resistance, screening.
Soil pathogens such as Pythium ultimum Trow. can cause severe damage in common bean (Phaseolus vulgaris L.). This fungus can infect the seeds, roots, and lower stem parts of the plant, and depending on the time of infection and prevailing environmental conditions, symptoms may be manifest as seed rot, preemergence and postemergence damping-off, root rot, dark brown or reddish roots, and sunken lesions on lower hypocotyls $(25,27,38,41)$. Damage during seed germination or lesions on the roots reduce plant density and plant growth, resulting in substantial reductions in yield and a lack of crop uniformity in the field. Environmental conditions such as soil temperature, poor soil drainage, or intensive cultivation in the same soil favor Pythium incidence $(2,22,37)$.

Traditionally, Pythium spp. is controlled by soil fumigation, seed treatments using different fungicides, cultural practices, and crop rotation $(16,22,23)$. However, these control methods are often ineffective; fungicide can be washed away with water, and these pathogens produce oospores that are highly persistent in soil and have wide host ranges (i.e., corn, soybean, wheat, pea, and cotton). The use of common bean cultivars with high levels of resistance is recommended to enhance effectiveness of integrated soil pathogen control strategies, including the control of Pythium spp. but cultivars resistant to this pathogen are either unavailable or unsuitable.

In common bean, limited information about sources of resistance or genetic control of P. ultimum is available. Resistance to seed rot and preemergence damping-off caused by $P$. ultimum has been associated with common bean genotypes with colored seeds. Differ-

Corresponding author: J. J. Ferreira; E-mail address: jjferreira@serida.org

doi:10.1094/PHYTO-06-10-0161

(c) 2010 The American Phytopathological Society ent screening methods found that common bean cultivars with colored seeds had higher levels of resistance to this fungus than whiteseeded cultivars $(7,9,24)$. Some studies also suggested quantitative inheritance of resistance to seed rot and preemergence dampingoff caused by $P$. ultimum $(32,45)$. However, other studies described a qualitative inheritance controlled by a single dominant gene (26).

The incidence of seed rot and preemergence damping-off in common bean is increasing in northern Spain, particularly in areas with intensive cultivation of white-seeded cultivars such as the market class fabada and ganxet. The main objectives of the present research were (i) to evaluate the response of a set of common bean genotypes against a local isolate of $P$. ultimum, and (ii) to investigate the inheritance of the resistance to a local isolate of P. ultimum and map quantitative trait loci (QTLs) in the recombinant inbred line (RIL) population developed from a cross between Xana and Cornell 49242. The information derived from this work will be useful for plant breeding programs.

\section{MATERIALS AND METHODS}

Pythium ultimum isolate. Isolate $\mathrm{Pu}-3$ of $P$. ultimum was obtained from a soil showing preemergence damping-off problems (Gallecs, Catalonia; 41 $34^{\prime} 14.15^{\prime \prime} \mathrm{N}, 2^{\circ} 11^{\prime} 42.43^{\prime \prime} \mathrm{E}$; elevation $124 \mathrm{~m}$; northeast Spain). The isolation was carried out using the selective media MPVM (pimaricin-vancomycin medium) (30). The isolate was derived from a unique hyphal tip. Identification of the species $P$. ultimum was performed using a specific molecular marker designed on portions of the sequence of the internal transcribed spacer (ITS) region (18). The pathogen cultures were maintained at $4^{\circ} \mathrm{C}$ with periodic transfers on potato dextrose agar plates (PDA; DIFCO, Becton, Dickinson and Company, Spark, $\mathrm{MD})$ and incubated in darkness at $24^{\circ} \mathrm{C}$. 
Plant material. The response against the P. ultimum isolate $\mathrm{Pu}-3$ was investigated in a set of 40 common bean materials maintained at the Servicio Regional de Investigación y Desarrollo Agroalimentario collection (Villaviciosa, Asturias, Spain) including: 11 cultivars used for anthracnose race characterization [Colletotrichum lindemuthianum (Sacc. \& Magnus) Lams.-Scrib]: Michelite, Michigan Dark Red Kindey (MDRK), Perry Marrow, Cornell 49242, Mexico 222, Widusa, Kaboon, PI-207262, TO, $\mathrm{TU}$, and $\mathrm{AB} 136$ (34); four lines used as resistant sources to anthracnose: A252, A321, A483, and A493 (12); six cultivars used for characterization of the pathogenic variability of Bean common mosaic virus (BCMV) and Bean common mosaic necrosis virus (BCMNV): Double white, Great Northern 31, Imuna, Jubila, Pinto 114, and Topcrop (10); four genotypes described as resistant sources to BCMV and BCMNV: Don Timoteo, BRB57, BRB130, and IVT7214; five lines described with moderate levels of resistance to white mold [Sclerotinia sclerotiorum (Lib.) de Bary]: A195, G122, Cornell 606, PC 50, and MO 162 (33); the lines BAT93 and Jalo EEP558 used as parents of a major core mapping population (13); two cultivars included in the market class fabada, Andecha and Xana; the cvs. Sanilac and Tendergreen used as reference for the two major gene pools, Middle American and Andean, described for the species (14); and genotypes A55, Negro de San Luis, Chinook, and Porrillo Sintético described with high levels of resistance to soil pathogens $(11,39)$.

A population of $92 \quad \mathrm{~F}_{7}$ RILs developed from the cross Xana/Cornell 49242 by single-seed descent method (XC RIL population) was used to investigate the inheritance of the response to this pathogen (36). Xana is a bean variety obtained in SERIDA (Villaviciosa, Asturias, Spain) with very large white seeds belonging to the fabada market class, and having determinate type I growth habit (42). Xana has a high susceptibility to P. ultimum. Cornell 49242 is a very small black-seeded line with indeterminate type III growth habit (42). It belongs to the Mesoamerican gene pool and is classified in the black turtle market class. Cornell 49242 has high levels of resistance to P. ultimum in local field tests.

Inoculum preparation and inoculation. Resistance tests were performed using the method described by Matoba et al. (27). The isolate was incubated on PDA at $24^{\circ} \mathrm{C}$ for 3 days and $0.5-\mathrm{cm}$ diameter mycelial plugs taken from the edge of the colonies were used for inoculation. A fresh mycelial plug was placed on each seed before covering with substrate. A replication consisted of ten seeds of each cultivar or line sown in a row of $30 \mathrm{~cm}$ in $6 \mathrm{~cm} \times$ $30 \mathrm{~cm} \times 40 \mathrm{~cm}$ plastic trays containing peat/perlite at 80:20. In each test, two replications per cultivar or line were sown in different plastic trays; one replication inoculated with the fungus and the other replication (used as check) inoculated with agar plugs only. Replications were arranged in a randomized complete block design in each test. Tests were carried out in summer of 2009 in a greenhouse and maintained at moderate temperature (from $16^{\circ} \mathrm{C}$ at night to $24^{\circ} \mathrm{C}$ during the day).

Disease assessment. The response of each material was assessed in four independent tests 15 to 18 days after planting (first trifoliate leaf totally opened) considering: (i) emergence rate or $\mathrm{ER}[(\mathrm{ER}=$ number of emerged seedlings from inoculated seeds $\times 100)$ /number of emerged seedlings in the check] and (ii) seedling vigor or SV, based on the first internode length (insertion of cotyledon to insertion of primary leaves) of the seedlings $[(\mathrm{SV}=$ first internode length in seedlings derived from inoculated seeds $\times 100)$ /first internode length in seedlings derived from seeds inoculated with agar].

Molecular mapping. A genetic map developed by Pérez-Vega et al. (36) in the XC RIL population was used to locate the genomic regions involving in the control of response to $P$. ultimum. The linkage map consisted of 175 amplified fragments length polymorphisms (AFLPs), 27 simple sequence repeats (SSRs), 30 sequence characterized amplified regions (SCARs), 33 inter-simple sequence repeats, 12 random amplified polymorphic DNAs, 13 loci coding for seed proteins, and the four genes: Fin,fin (growth habit); Asp,asp (seed coat shininess); P,p (seed color); and $I, i$ (resistance to BCMV). Twenty-four additional SSR loci $(15,17)$ were added to the map published by Perez-Vega et al. (36). For the map construction, the software MAPMAKER Macintosh version 2.0 and a minimum LOD (logarithm of the odds) of 3.0 were used (20). Distances between loci (cM) were calculated using the Kosambi mapping function. The obtained map had 11 linkage groups, aligned to the core linkage map of bean using common molecular markers as anchor points. Linkage groups were named according to Pedrosa-Harand et al. (35).

Data analysis. Chi-square was used to test goodness-of-fit of observed to expected ratio (1:1) in the qualitative traits, and linkage analysis was performed using the MAPMAKER Macintosh version 2.0. Frequency distributions for the quantitative traits were tested for normality using the Kolmogorov-Smirnov test, and $P<0.05$ was used to indicate lack of fit. Analysis of variance followed by least significant difference (LSD) tests and $t$ tests were used to determine significant differences $(P<0.05)$ among means. Pearson's correlations were used to investigate the degree of agreement among the mean phenotypic data obtained from the different tests. Statistical analyses were performed using SPSS V12 software (SPSS Inc., Chicago, IL).

QTLs were located on the genetic map using the QTL Cartographer V2.5 software (43). QTLs were detected by composite interval mapping (CIM) analysis using a window size of $10 \mathrm{cM}$ (walkspeed). A LOD score of 2.5 was used as the threshold to determine the presence of significant QTLs. This value was estimated using a permutation analysis with 1,000 random data shuffles (6) to provide genome-wide significance at $P<0.05$. QTLs identified from the mean of the four tests and in at least two different tests were considered to be consistent. Identified QTLs were named according to Miklas and Porch (29).

\section{RESULTS}

Reactions of the common bean lines and cultivars to $P$. ultimum. The response of emergence rate and seedling vigor of 40 common bean genotypes to the local isolate Py-3 of P. ultimum varied among genotypes (Table 1). For emergence rate, high and significant correlations ( $r=0.92$ to $0.96 ; P<0.001$ ) were found among the four tests, indicating the correspondence among the data from the different tests. Fourteen genotypes, all with white seeds, exhibited emergence equal or not significantly different to 0\%. These genotypes included Xana, Perry Marrow, A493, BRB57, BRB130, IVT7214, Imuna, Jubila, Andecha, Kaboon, Mexico 222, Great Northern 31, Double white, and Widusa. All these genotypes showed symptoms of seed rot or preemergence damping-off. In contrast, a total of 14 genotypes, all with colored seeds, had percentages of germination not significantly different from 100\% emergence: MO162, Cornell 49242, A483, A195, Tendergreen, AB136, Cornell 606, Jalo EPP558, A55, Porrillo Sintético, A252, Negro San Luis, Pinto 114, and A321. Twelve genotypes, including both colored and white seeds, showed intermediate percentages of emergence after inoculation, significantly different to both 0 and $100 \%$ emergence. Cultivars Michelite and Sanilac, both classified in the market class navy, exhibited moderate emergence rate. There was a significant difference in emergence rates between genotypes with colored seed and those with white seed $(t=7.4 ; P<0.001)$.

Phenotypic variation in seedling development, color of leaves, and damage to roots was observed in the germinated seedlings of some genotypes compared with controls. Twenty-two genotypes with emergence rate $\geq 30 \%$ were assessed for seedling vigor. Significant correlations among the four tests were not found in all cases for seedling vigor, indicating that this trait could be conditioned by other factors besides the pathogen. A total of 11 
genotypes had seedling vigor not significantly different to $100 \%$ (i.e., similar to growth of control): Don Timoteo, MO162, Tendergreen, Cornell 606, Jalo EPP558, A55, Porrillo sintético, A252, Negro San Luis, Pinto 114, and A321. In these 11 genotypes, the phenotypes of seedlings derived from inoculated seeds were similar to the control phenotype. In the remaining 11 genotypes, seedlings derived from inoculated seeds showed less development compared with controls and had symptoms associated with $P$. ultimum infection such as dark brown roots or root rot. Finally,

TABLE 1. Reaction of selected common bean cultivars and breeding lines to a local isolate of Pythium ultimum $^{\mathrm{a}}$

\begin{tabular}{|c|c|c|c|}
\hline Genotypes & Seed color & Emergence rate $(\%)$ & Seedling vigor $(\%)$ \\
\hline Xana & White & 0.0 & - \\
\hline Perry Marrow & White & 0.0 & - \\
\hline A493 & White & 0.0 & - \\
\hline BRB57 & White & 0.0 & - \\
\hline BRB130 & White & 0.0 & - \\
\hline IVT7214 & White & 0.0 & - \\
\hline Imuna & White & 0.0 & - \\
\hline Jubila & White & 0.0 & - \\
\hline Andecha & White & 0.0 & - \\
\hline Kaboon & White & 0.0 & - \\
\hline Mexico 222 & White & 2.5 & - \\
\hline Great Northern 31 & White & 3.6 & - \\
\hline Double White & White & 4.2 & - \\
\hline Widusa & White & 10.8 & - \\
\hline Michelite & White & 17.5 & - \\
\hline PI207262 & Colored & 17.5 & - \\
\hline Sanilac & White & 23.9 & - \\
\hline MDRK & Colored & 28.3 & - \\
\hline Topcrop & Colored & 52.5 & 61.2 \\
\hline BAT 93 & Colored & 52.8 & 71.1 \\
\hline TU & Colored & 63.6 & 75.4 \\
\hline TO & Colored & 63.6 & 69.4 \\
\hline Don Timoteo & Colored & 72.2 & 87.0 \\
\hline G122 & Colored & 72.5 & 69.6 \\
\hline Chinook & Colored & 82.5 & 82.3 \\
\hline PC50 & Colored & 82.5 & 84.3 \\
\hline MO162 & Colored & 86.9 & 86.9 \\
\hline Cornell 49242 & Colored & 87.5 & 83.3 \\
\hline A483 & Colored & 88.9 & 83.7 \\
\hline A195 & Colored & 95.0 & 73.4 \\
\hline Tendergreen & Colored & 95.0 & 98.2 \\
\hline AB136 & Colored & 97.5 & 84.0 \\
\hline Cornell 606 & Colored & 97.5 & 90.7 \\
\hline Jalo EPP558 & Colored & 97.5 & 96.4 \\
\hline A55 & Colored & 97.5 & 100.0 \\
\hline Porrillo sintetico & Colored & 100.0 & 88.5 \\
\hline A252 & Colored & 100.0 & 91.6 \\
\hline Negro San Luis & Colored & 100.0 & 98.6 \\
\hline Pinto 114 & Colored & 100.0 & 98.8 \\
\hline A321 & Colored & 100.0 & 100.0 \\
\hline LSD $(0.05)$ & & 15.0 & 13.7 \\
\hline
\end{tabular}

${ }^{a}$ The response was assessed as emergence rate and seedling vigor. The replications used as check showed a percentage of germination $>85 \%$ in the four tests. there was a high and significant correlation between emergence rate and seedling vigor $(r=0.69, P<0.001)$.

Response of the XC RIL population. Cultivars Xana and Cornell 49242 showed significant differences in the responses to P. ultimum (Table 1): cv. Xana had high susceptibility (0\% emergence) while cv. Cornell 49242 had high levels of resistance (87\% emergence). The response to $P$. ultimum was investigated in a population of $92 \mathrm{~F}_{2: 7}$ RILs derived from the cross Xana/Cornell 49242. There were high and significant correlations $(r=0.80$ to $0.86 ; P<0.001)$ among the four tests for emergence rate and this trait did not fit a normal distribution, suggesting involvement of qualitative loci in its genetic control (Fig. 1). A total of 47 RILs (44 white-seeded and three colored) showed $0 \%$ emergence, while the remaining 45 RILs (all with colored seed) had different levels of emergence within 10 to $100 \%$. Lines with white seed coats and also some level of emergence were not found. Among lines with colored seed, the highest levels of emergence were not significantly associated with black seed color; there was no significant difference between lines with black seed coats and lines of other colors $(t=1.43, P>0.05)$. There was a significant and negative correlation between emergence rate and seed weight ( $r=-0.45, P<0.001)$ in this RIL population. Considering two main phenotypic classes, nonemergence (like the parent Xana) and emergence, the obtained segregation 47:45 fitted a monogenic mode of inheritance $\left(\chi_{1: 1}^{2}=0.04 ; P=0.83\right)$. This hypothetical locus involved in the response to $P$. ultimum was located in the genetic map developed by Pérez-Vega et al. (36) at the LG 7, close to the gene $P$ (Fig. 2).

In the subpopulation of RIL which generated seedlings (45 lines with colored seeds), there were nonsignificant deviations from the corresponding normal distributions for emergence rate and seedling vigor, thus supporting their quantitative inheritance (Fig. 1). Both traits were significantly correlated between them $(r=0.49 ; P<0.05)$. Using this subpopulation, a QTL $\left(\mathrm{ER} 3^{\mathrm{XC}}\right)$ explaining $13 \%$ of phenotypic variance was identified for emergence rate (Fig. 2). This QTL was located in LG 3 (Table 2) and the alleles contributed by the parent Xana increased the trait (i.e. higher levels of emergence). Significant correlations among the results supplied by the four tests were not found in all cases for seedling vigor. One significant QTL $\left(\mathrm{SV}^{\mathrm{XC}}\right.$ ) accounted for $32 \%$ of phenotypic variance for seedling vigor was identified in LG 6 (Fig. 2). The allele contributed by the parent Cornell 49242 increased seedling vigor. The closest markers associated to the QTLs ER3 ${ }^{\mathrm{XC}}$ and $\mathrm{SV} 6^{\mathrm{XC}}$ were the AFLP fragments MctaEta ${ }^{69}$ and MctgEat $^{141}$, respectively (Fig. 2; Table 2).

\section{DISCUSSION}

Evaluation of 40 common bean genotypes showed an association between the seed coat color and response to P. ultimum. The higher levels of resistance (in emergence rate and seedling vigor) were exhibited in genotypes with black seed (i.e., A55, Porrillo Sintético, and Negro de San Luis) or dark seed (i.e., A321, A252,
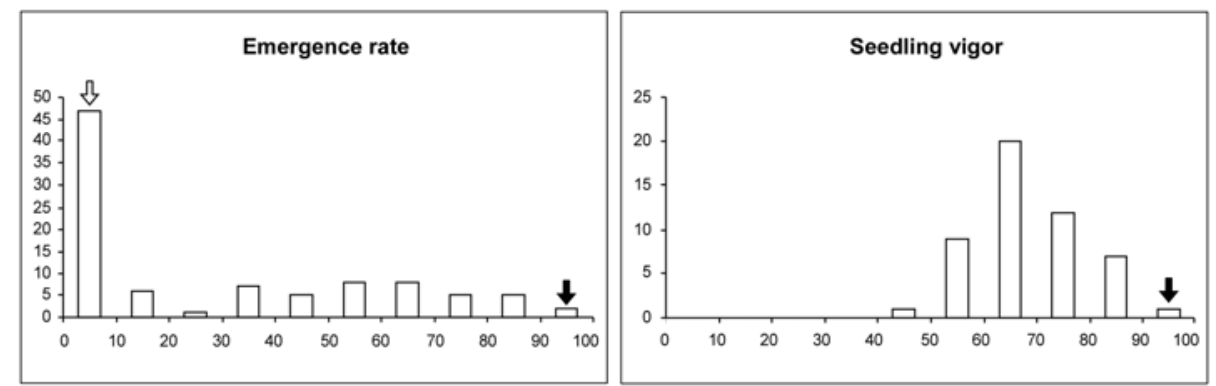

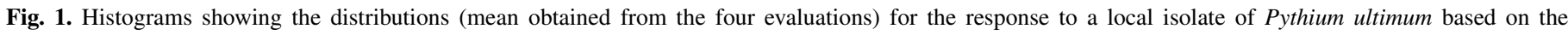
percentage of emergence (\%) and the seedling vigor (\%). Black and white arrows indicate the phenotypic values of parents Cornell 49242 and Xana, respectively. 

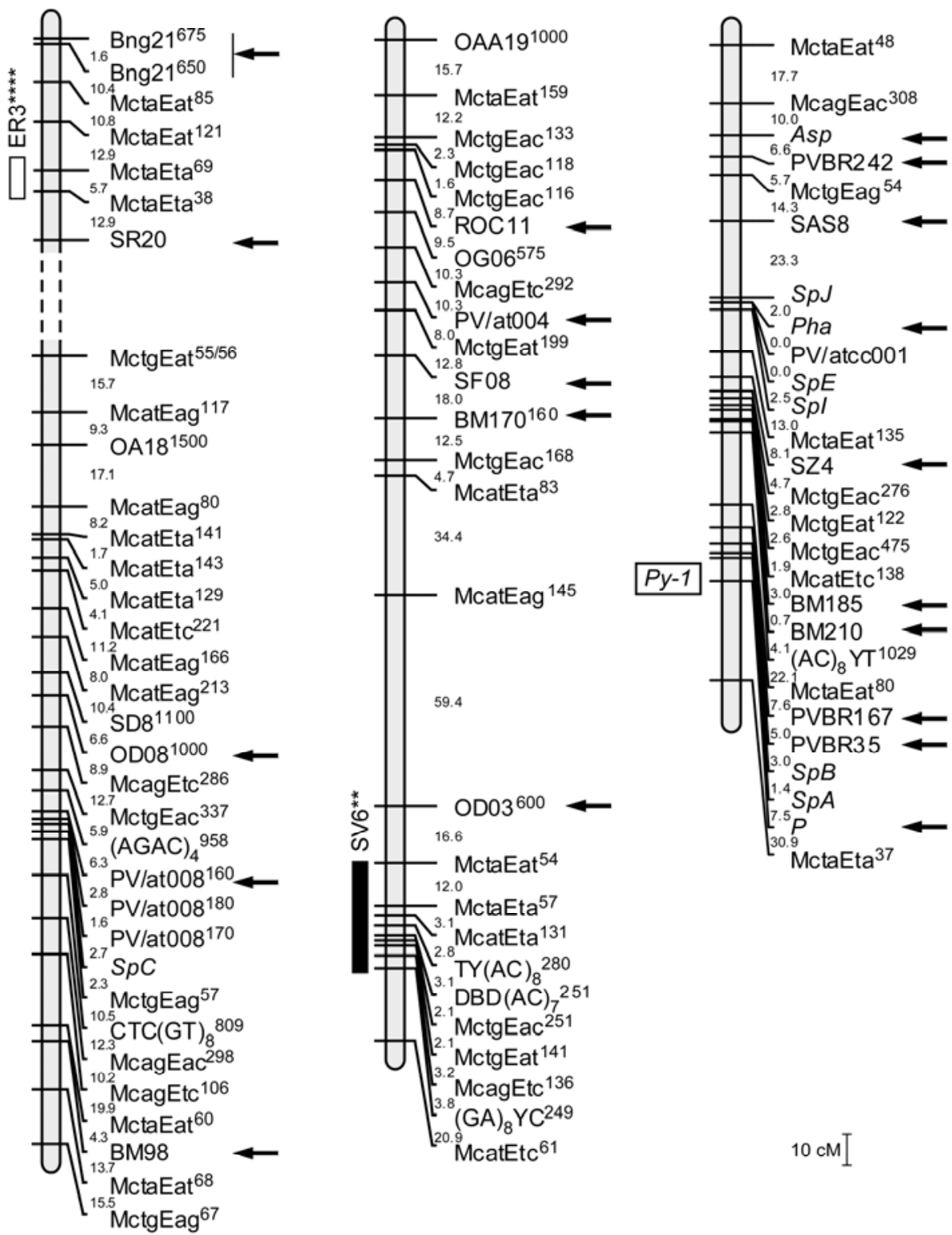

Fig. 2. Linkage groups in which qualitative or quantitative loci for the response to a local isolate of Pythium ultimum were detected using the common bean recombinant inbred line population Xana/Cornell 49242 (33). Arrows indicate common loci to previously published maps. Distances between loci (cM) are showed in the left of the locus names. Prefixes Pha end Sp- indicate phaseolin protein and seed proteins, respectively; prefix M-, amplified fragment length polymorphism fragments; prefixes BM-, BMd-, Bng-, and PV- microsatellite markers; prefix O-, random amplified polymorphic DNA fragments; prefix S-, sequence characterized amplified region markers. Inter-simple sequence repeats fragments were named using the respective sequence of the primer. The estimated size of the fragments is indicated superscript. Black and white vertical bars represent quantitative trait loci (QTL) in which the increase is supported by the alleles of Cornell 49242 and Xana, respectively. The number of asterisks near the name of the QTL indicates the number of tests in which the QTL was detected.

and Pinto 114). The cv. Sanilac had the highest emergence rate among the white-seeded cultivars, confirming observations of Beebe et al. (4). The level of resistance in cv. Sanilac was significantly lower than the best sources of resistance identified, and so this genotype would not be recommended as a resistance source for a breeding program focused on increasing resistance to $P$. ultimum. Previous studies investigating the response to $P$. ultimum also showed higher levels of resistance in genotypes with colored seeds than those with white seeds $(7,9,24)$. Seed coat color in common bean is controlled by several loci with complex epistatic interactions and, in some cases, different alleles (21). The locus $P$ is a basic color gene involved in control of seed coat color; in recessive genotypes the seed coat is pure white. The recessive allele at the locus is interpreted as giving a lower level or absolute lack of the first enzyme involved in pigment production (21). White-seeded phenotypes can also be produced by at least another four genotypes $(3,21)$, and has been used in strategies to develop cultivars with white seeds and moderate levels of damping-off resistance (8).

The response to $P$. ultimum, assessed as emergence rate, in the XC RIL population suggests both qualitative and quantitative modes of inheritance. A major gene $(P y-1)$ is involved in the genetic control of resistance to seed decay and preemergence damping-off. This gene was located in LG 7, closely linked to the $P$ gene. A qualitative inheritance for the response to $P$. ultimum was also observed in segregating populations derived from the line RWR 719 (25) and in other crops, such as pea, maize, and soybean $(31,40,44)$. Among lines with colored seed in the $\mathrm{XC}$ RIL population, there was a wide range of emergence rate $(0$ to $100 \%$ ), indicating quantitative inheritance in this subpopulation. Three lines with colored seed exhibited a $0 \%$ emergence rate. This result suggests that other additional loci, apart from the $P y-1$ 
TABLE 2. Quantitative trait loci (QTL) for the reaction to Pythium ultimum identified using composite interval mapping analysis in the subpopulation of 45 recombinant inbred lines derived from the cross between Xana and Cornell 49242 which generated seedlings after the inoculation

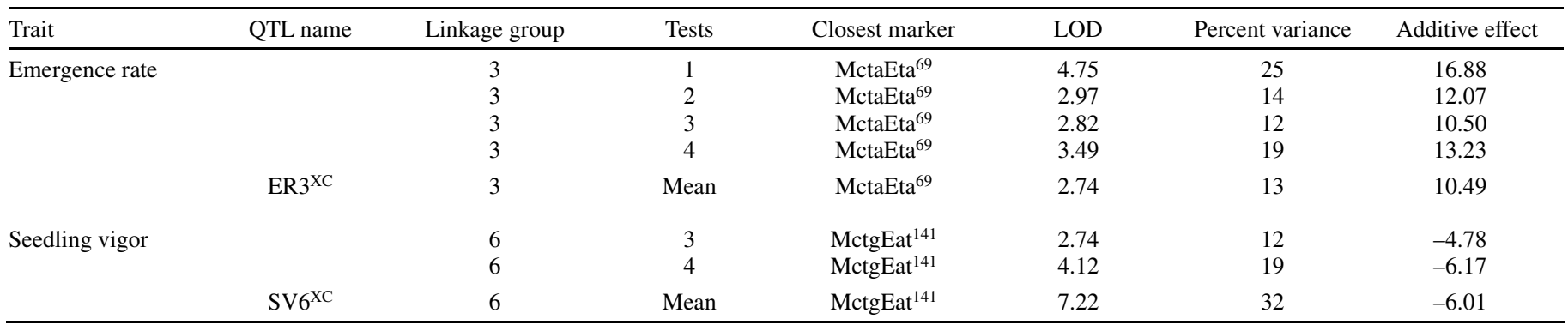

gene, are involved in genetic control of resistance to P. ultimum. Quantitative inheritance for the response to P. ultimum was described in the white-seeded snap bean line 1273 using artificial inoculation (45). A similar response was found in fields naturally infected with P. ultimum and Aphanomyces euteiches for the number of germinated seedlings in a RIL population derived from a cross between resistant lines Puebla 152 and Eagle (32). A specific allele combination for the QTL associated with emergence rate could explain the identification of three lines with colored seed coat and $0 \%$ emergence.

Using the RIL subpopulation which generated seedlings, the response to $P$. ultimum was also analyzed. Small population sizes can overestimate QTL (1) although the linkage map used in this study is highly saturated of loci (>300). A significant QTL $\left(\mathrm{ER}^{\mathrm{XC}}\right)$ was identified, located in LG 3, controlling the emergence rate while another QTL $\left(\mathrm{SV}^{\mathrm{XC}}\right)$ associated with the seedling vigor, a trait based on the first internode length, was located in LG 6. The finding of larger QTL for seedling vigor $\left(R^{2}=32 \%\right)$ in Cornell 49242 parent in LG 6 might correspond with another color locus know as the $V$ locus that maps to this region of the bean genome (28). The strong association between seed coat color (associated flavanoid compounds) and resistance to Pythium is well documented $(7,9,24)$ and a second locus in Cornell 49242 associated with the V color locus is not unexpected. On the other hand, QTLs associated with length of the first internode were mapped in different relative positions: (i) in this same RIL population two QTLs associated to first internode length were located on the LG 1 (fin region; IL1 ${ }^{\mathrm{XC}}$ ) and LG 11 $\left(\mathrm{IL} 11^{\mathrm{XC}}\right.$ ) in a different study (data not shown). The amount of phenotypic variation explained by each QTL was 24 and 6\%, respectively; (ii) in the Midas/G12873 RIL population a QTL associated to this trait was mapped in the LG 1 (19). Seedling vigor was positively and significantly correlated with the emergence rate both in the response of the 40 common bean genotypes and also the RIL subpopulation, suggesting a relationship between this measure and reaction to $P$. ultimum. This relationship is also consistent with independence between QTLs associated with length of the first internode and the QTL SV6 ${ }^{\mathrm{XC}}$.

Considering common markers among the Eagle/Puebla 152 map (32), the bean core map $(5,13)$ and the map used in this work enables some interesting deductions. (i) A QTL associated with plant vigor and biomass using field tests was located on LG 6 by Navarro et al. (32). The relative position of this QTL associated with the traits of plant vigor and biomass did not correspond with the relative position of the QTL SV6 ${ }^{\mathrm{XC}}$ identified in the present study; they are located in different extremes of chromosome. (ii) A QTL associated with the trait plant stand, a trait similar to emergence as assessed in the present study, was mapped in a position of the gene $P$ (32). In this region QTLs associated with seed traits (seed width and coat proportion) were previously mapped in the XC RIL population (36). The association of the same genomic regions with genetic control of response to $P$. ultimum and seed traits could indicate an avoidance mechanism more than physiological resistance. In general, genotypes with large seeds such as the market class fabada need more time to germinate and are therefore more exposed to pathogen attack and seed decay. This hypothesis is consistent with the significant and negative correlation observed between seed weight and emergence in the XC RIL population; recombinant lines with large seed generally had a lower emergence than lines with smaller seeds. This hypothesis could also explain the moderate levels of emergence of cvs. Michelite and Sanilac, genotypes with very small seeds.

The results suggested both qualitative and quantitative modes of inheritance in the response to $P$. ultimum involving three different genomic regions. The regions of the LG 3 and 6 are saturated by AFLP fragments, a type of molecular marker difficult to be used in marker-assisted selection. Addition to these two LG of new markers such as specific SSR or SCAR described in the species $(15,17)$ could provide better tools for the marker-assisted selection. The results also revealed a strong relationship between genetic control of seed coat color (region of $P$ gene in the LG 7) and response to $P$. ultimum. Although a previous study indicated that this association can be broken and genotypes with moderate levels of resistance and white seed coat were described $(4,45)$, the presence of color in the seed coat seems to be a determining factor in protection against this pathogen during germination. The development of wide segregating populations to produce recombinations could supply genotypes with white seed coats and also high levels of resistance to this pathogen.

\section{ACKNOWLEDGMENTS}

We thank P. N. Miklas and L. Porter (USDA-ARS, Prosser, WA) for assistance in the resistance tests. This work was supported by grants AGL2007-66563-C02-02 from the Ministerio de Ciencia y Tecnología, Spain. A. Pascual was recipient of fellowship from the Caja Rural de Gijón (Spain). E. Pérez-Vega was recipient of fellowship from the Instituto Nacional de Investigación y Tecnología Agraria y Alimentaria (INIA, Spain).

\section{LITERATURE CITED}

1. Asíns, M. J. 2002. Present and future of quantitative trait locus analysis in plant breeding. Plant Breed. 121:281-291.

2. Ayers, W. A., and Lumsden, R. D. 1975. Factors affecting production and germination of oospores of three Pythium species. Phytopathology 65:1094-1100.

3. Bassett, M. J., and Blom, A. 1991. A new genotype for white seed coat discovered in 'early wax' snap bean. J. Am. Soc. Hort. Sci. 116:131-136.

4. Beebe, S. E., Bliss, F. A., and Schwartz, H. 1981. Root rot resistance in common bean germ plasm of Latin America origin. Plant Dis. 65:485489.

5. Blair, M. W., Pedraza, F., Buendía, H. F., Gaitán-Solís, E., Beebe, S. E., Gepts, P., and Tohme, J. 2003. Development of a genome-wide anchored microsatellite map for common bean (Phaseolus vulgaris L.). Theor. Appl. Genet. 107:1362-1374.

6. Churchill, G. A., and Doerge, R. W. 1994. Empirical threshold values for quantitative trait mapping. Genetics 138:963-971.

7. Deakin, J. R. 1974. Association of seed color with emergence and seed yield of snap beans. J. Am. Soc. Hort. Sci. 99(2):110-114. 
8. Dickson, M. H., and Abawi, G. S. 1974. Resistance to Pythium ultimum in white-seeded beans (Phaseolus vulgaris). Plant Dis. Rep. 58:774-776.

9. Dickson, M. H., and Petzoldt, R. 1988. Deleterious effects of white seed due to $p$ gene in beans. J. Am. Soc. Hort. Sci. 113:111-114.

10. Drijfhout, E. 1978. Genetic interaction between Phaseolus vulgaris and common mosaic virus with implications for strain identification and breeding for resistance. Centre from Agricultural Publishing and Documentation, Wageningen, The Netherlands.

11. Falconi, E., Murillo, A., Pinzón, J., Peralta, E., and Abawi, G. 2007. Identification of root rot resistance sources in common bean. Ann. Rep. Bean Improv. Coop. 50:139-140.

12. Ferreira, J. J., Campa, A., Pérez-Vega, E., and Giraldez, R. 2008. Reaction of a bean germplasm collection against five races of Colletotrichum lindemuthianum identified in northern Spain and implications for breeding. Plant Dis. 92:705-708.

13. Freyre, R., Skroch, P. W., Geffroy, V., Adam-Blondon, A. F., Shirmohamadali, A., Johnson, W. C., Llaca, V., Nodari, R. O., Pereira, P. A., Tsai, S. M., Tohme, J., Dron, M., Nienhuis, J., Vallejos, C. E., and Gepts, P. 1998. Towards an integrated linkage map of common bean. 4 . Development of a core linkage map and alignment of RFLP maps. Theor. Appl. Genet. 97:847-856.

14. Gepts, P., Osborn, T. C., Rashka, K., and Bliss, F. A. 1986. Phaseolinprotein variability in wild forms and landraces of the common bean (Phaseolus vulgaris): Evidence for multiple centers of domestication. Econ. Bot. 40:451-468.

15. Grisi, M. C. M., Blair, M. W., Gepts, P., Brondani, C., Pereira, P. A. A., and Brondani, R. P. V. 2007. Genetic mapping of a new set of microsatellite markers in a reference common bean (Phaseolus vulgaris) population BAT93x Jalo EEP558. Genet. Mol. Res. 6:691-706.

16. Hall, R., and Nasser, L. C. B. 1996. Practice and precept in cultural management of bean diseases. Can. J. Plant Pathol. 18:176-185.

17. Hanai, L. R., Santini, L., Camargo, L. E. A., Pelegrinelli, M. H., Gepts, P., Tsai, S. M., and Vieira, M. L. C. 2010. Extension of the core map of common bean with EST-SSR, RGA, AFLP, and putative functional markers. Mol. Breed. 25:25-45.

18. Kageyama, K., Ohyama, A., and Hyakumachi, M. 1997. Detection of Pythium ultimum using polymerase chain reaction with species-specific primers. Plant Dis. 81:1155-1160.

19. Koinange, E. M. K., Singh, S. P., and Gepts, P. 1996. Genetic control of the domestication syndrome in common bean. Crop Sci. 36:1037-1044.

20. Lander, E. S., Green, P., Abrahamson, J., Barlow, A., Daly, M. J., Lincoln, S. E., and Newburg, L. 1987. MAPMAKER: An interactive computer package for constructing primary genetic linkage maps of experimental and natural populations. Genomics 1:174-181.

21. Leakey, C. L. A. 1988. Genotypes and phenotypes markers in common bean. Pages 245-327 in: Genetic Resources of Phaseolus Beans. P. Gepts, ed. Kluwer Academic, Boston, MA.

22. Lewis, J. A., Lumsden, R. D., Papavizas, G. C., and Kantzes, J. G. 1983. Integrated control of snap bean diseases caused by Pythium spp. and Rhizoctonia solani. Plant Dis. 67:1241-1244.

23. Locke, J. C., Papavizas, G. C., Lewis, J. A., Lumsden, R. D., and Kantzes, J. B. 1983. Control of Pythium blight of snap beans by seed treatment with systemic fungicides. Plant Dis. 67:974-977.

24. Lucas, B., and Griffiths, P. D. 2004. Evaluation of common bean accessions for resistances to Pythium ultimum. HortScience 39:11931195 .

25. Lumsden, R. D., Ayers, W. A., Adams, P. B., Dow, R. L., Lewis, J. A., Papavizas, G. C., and Kantzes, J. G. 1976. Ecology and epidemiology of Pythium species in field soil. Phytopathology 66:1203-1209.

26. Mahuku, G. S., Buruchara, R. A., and Navia, M. 2005. A gene that confers resistance to Pythium root rot in common bean: Genetic characterization and development of molecular markers. Phytopathology 95:S64.

27. Matoba, Y., Kondo, N., Akino, S., Kodama, F., Naito, S., and Ebe, S. 2008. Identification and pathogenicity of Pythium species causing damping-off of kidney bean. J. Gen. Plant Pathol. 74:81-85.

28. McClean, P. E., Lee, R. K., Otto, C., Gepts, P., and Bassett, M. J. 2002. Molecular and phenotypic mapping of genes controlling seed coat pattern and color in common bean (Phaseolus vulgaris L.). J. Hered. 93:148-152.

29. Miklas, P. N., and Porch, T. 2010. Guidelines for common bean QTL nomenclature. Annu. Rep. Bean Improv. Coop. 53:202-203.

30. Mircetich, S. M., and Kraft, J. M. 1973. Efficiency of various selective media in determining Pythium population in soil. Mycopathologia 50:151-161.

31. Muehlbauer, F. J., and Kraft, J. M. 1978. Effect of pea seed genotype on pre-emergence damping-off and resistance to Fusarium and Pythium root rot. Crop Sci. 18:321-323.

32. Navarro, F., Sass, M. E., and Nienhuis, J. 2008. Identification and confirmation of quantitative trait loci for root rot resistance in snap bean. Crop Sci. 48:962-972.

33. Pascual, A., Campa, A., Pérez-Vega, E., Giraldez, R., and Ferreira, J. J. 2010. Screening common bean for resistance to four Sclerotinia sclerotiorum isolates collected in northern Spain. Plant Dis. 94:885-890.

34. Pastor-Corrales, M. A. 1991. Estandarización de variedades diferenciales y designación de razas de Colletotrichum lindemuthianum. (Abstr.) Phytopathology 81:694.

35. Pedrosa-Harand, A., Porch, T., and Gepts, P. 2008. Standard nomenclature for common bean chromosomes and linkage groups. Annu. Rep. Bean Improv. Coop. 51:106-107.

36. Pérez-Vega, E., Pañeda, A., Rodríguez-Suárez, C., Campa, A., Giraldez, R., and Ferreira, J. J. 2010. Mapping of QTLs for morpho-agronomic and seed quality traits in a RIL population of common bean (Phaseolus vulgaris L.). Theor. Appl. Gent. 120:1367-1380.

37. Pieczarka, D., and Abawi, G. S. 1978. Populations and biology of Pythium species associated with snap bean roots and soils in New York. Phytopathology 68:409-416.

38. Reeleder, R. D., and Hagedorn, D. J. 1981. Inheritance of resistance to Pythium myriotylum hypocotyl rot in Phaseolus vulgaris L. Plant Dis. 65:427-429.

39. Román-Avilés, B., and Kelly, J. D. 2005. Identification of quantitative trait loci conditioning resistance to Fusarium root rot in common beans. Crop Sci. 45:1881-1890.

40. Rosso, M. L, Rupe, J. C., Chen, P., and Mozzoni, L. A. 2008. Inheritance and genetic mapping of resistance to Pythium damping-off caused by Pythium aphanidermatum in 'Archer' soybean. Crop Sci. 8:2215-2222.

41. Schwartz, H. F., Steadman, J. R., Hall, R., and Forster, R. L. 2005 Compendium of Bean Diseases. 2nd ed. American Phytopathological Society, St. Paul, MN.

42. Singh, S. P. 1982. A key for identification of different growth habits of Phaseolus vulgaris L. Annu. Rep. Bean Improv. Coop. 25:92-94.

43. Wang, S., Basten, C. J., and Zeng, Z. B. 2005. Windows QTL Cartographer 2.5. Department of Statistics, North Carolina State University, Raleigh, NC.

44. Yang, D. E., Jin, D. M., Wang, B., Zhang, D. S., Nguyen, H.-T., Zhang, C. L., and Chen, S. J. 2005. Characterization and mapping of Rpil, a gene that confers dominant resistance to stalk rot in maize. Mol. Gen. Genomics 274:229-234.

45. York, D. W., Dickson, M. H., and Abawi, G. S. 1977. Inheritance of resistance to seed decay and pre-emergence damping-off in snap beans caused by Pythium ultimum. Plant Dis. Rep. 61:285-289. 